ST ATE OF ILLINOIS

DEPARTMENT OF REGISTRATION AND EDUCATION

DIVISION OF THE

NATURAL HISTORY SURVEY

STEPHEN A. FORBES. Chief

\begin{tabular}{lll}
\hline Vol. XVII. & BULLETIN & Article V. \\
\hline
\end{tabular}

\title{
Some Properties of Oil Emulsions Influencing Insecticidal Efficiency
}

BY

L. L. ENGLISH

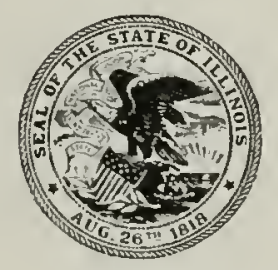


STATE OF ILLINOIS

DEPARTMENT OF REGISTRATION AND EDUCATION

A. M. SneLtox, Director

BOARD OF

NATURAL RESOURCES AND CONSERVATION

A. MI. ShrLtox, Chairman

Willis.s TreLease. Biology

Hexro C. Cowles. Forestry

Eusox S. Bastix, Geology

William A. Nores, Chemistry
Jolls W. Altond. Engincering

Charles M. Thompsox, Representing the Prcsident of the University of Illinois

THE NATURAL HISTORY SURVEY DIVISION

Stepifen A. Forues, Chief

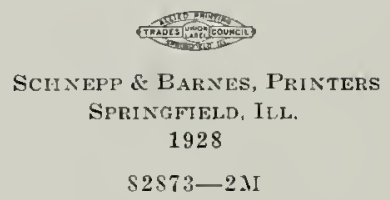




\section{FOREWORD}

The first sprays used for combatting San fose scale when it became established in the United States were made mainly from light oils, stuch as kerosene. Kerosene emulsion, one of the principal insecticides in use at that time, was first recommended for the control of San Jose scale by Joln B. Smith, of the New Jersey Agricultural Experiment Station, in 18:\%. During the next few years, when oil sprays were being tried for this purpose in many parts of the conntry, little attention was given to the standarlization of the emulsion, and in some cases kerosene and water were applied in the form of a mechunical mixture mate by forcing the two materials througl a spray pump and mixing them in two jets discharged from the spray nozzle. Much injury restilted and many trees were killed. so that oil sprays as a class were more or less in disrepute for a number of years. Since 1!1:, however, there has been a marlied increase in the use of oil sprays, due largely to the work of liederal and State entomologists with the so-called lubricating oil emulsions. These emulsions, made by several different formulae. have proved very effective and have largely taken the place of lime-sulfur in domant spraying for the control of San Jose and other scale insects.

Entomologists and horticulturists generally lave recognized that oil spays as a class, while very effective, are dangerous to use unless properly prepared. In order to be sure that a spray is safe, we need to know its exact effect on insects and plants. This means that we must recognize differences in oils and differences in ennusifying agents, so as to learn what kind of emulsion to use for the result rlesired.

In the hope of throwing sone light on these important questions concerning the use of oil sprays, the investigation herein reported by $\mathrm{M}$. English was undertalien in February, 19.25, on a (rop Protection Institute fellowship established by the Standard Oil Company of Indiana. The project was directed by a committee composed of $\mathbb{W}$. P. Flint. J. S. Honser, J. J. Davis, and WI. C. O'Kane, and the work was done at Lribana, Illinots, in cooperation with the Illinois State Natural History Survey.

December, 192:

W. P. FLINT. 


\section{CONTENTS}

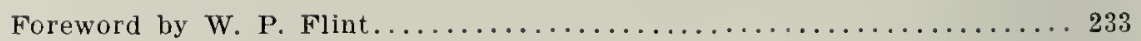

Introduction $\ldots \ldots \ldots \ldots \ldots \ldots \ldots \ldots \ldots \ldots \ldots \ldots \ldots \ldots \ldots \ldots \ldots \ldots$

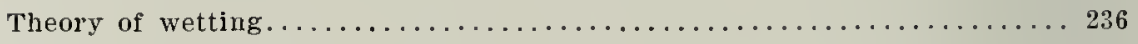

Angle-of-contact measurements $\ldots \ldots \ldots \ldots \ldots \ldots \ldots \ldots \ldots \ldots \ldots \ldots \ldots \ldots$

Relation between wetting ability and toxicity to aphids........... 240

Relation of chemical property of oil and stability of emulsion to effective-

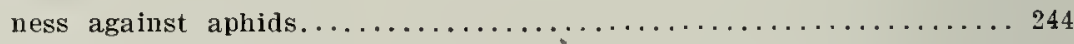

Relation between wetting ability and toxicity to San Jose scale and oystershell scale

Relation of volatility and viscosity of oil to effectiveness against scale insects

Relation of chemical property of oil and stability of emulsion to effectiveness against scale insects.

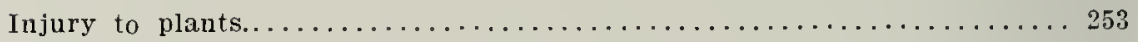

Conclusions $\ldots \ldots \ldots \ldots \ldots \ldots \ldots \ldots \ldots \ldots \ldots \ldots \ldots \ldots \ldots \ldots \ldots \ldots \ldots \ldots$

Acknowledgments $\ldots \ldots \ldots \ldots \ldots \ldots \ldots \ldots \ldots \ldots \ldots \ldots \ldots \ldots \ldots \ldots$

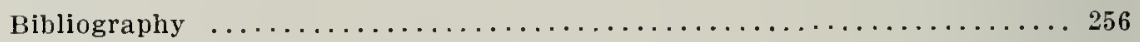

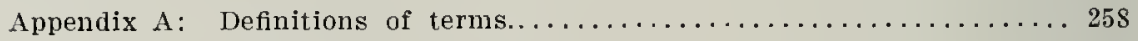

Appendix B: Experimental methods ..................... 259

Appendix $\mathrm{C}:$ Analysis of tap water used in experiments.......... 259 


\section{SOME PROPERTIES OF OIL WMULSIONS INFLUENGING INSECTICIDAL EFFICIENCI*}

\section{L. English}

An insect's initial experience with an oil emulsion is physical. After the contact or the physical reaction, there may be chemical action. Oil, the killing agent used in emulsions, is not highly active chemically, and the oil globules are given a "coat" of material which usual!y is even less active chemically. As Woodman ('24) points out: "The tailure of a spray is not usually due to a lack of toxicity but rather to the absence of certain desirable physical properties." These properties have been considered in the investigations of Cooper and Nuttall ('15). Noore and Graham ('18), and others, but their importance has not been given sufficient attention in actual spray practice.

The term "oil emulsion" is often used with the incorrect inference that all oil emulsions are alike. Some emulsions are suitable for application to foliage, while others are not. Some are more effective than others on scale insects, and those that are effective on scale insects may not be effective on aphids. The more the subject is investigated, the greater becomes the variety of oils and the larger the number of emulsifying agents encountered. Each oil, each emulsifier, and each class of insect pest introduces factors that must be considered more or less separately.

It is very difficult to isolate any one property of an emulsion and determine separately its action on insects. The physical and chemical properties of the oil, the kind and amonnt of emulsifying agent, and the stability of the emulsion are all so closely interlocked that one property usually camnot be varied without changing the others. There is good reason for believing that no two emulsions-and, very likely, no two lot: of an emulsion made by the same formula-are cractly alike. The "individuality" of any emulsion will depend upon the way in which it is put together. the manner and duration of manipulation, the type and amount of emulsifying agent, the kind of oil, the quality of water, and the tenperature at the time of dispersion. Ordinarily. With the same amount of

* This paper was submitted as a thesis for the degree of doctor of philosophy in entomolrgy at Towa state college of Agriculture, $192 \bar{t}$ 
emulsifying agent, and the same treatment, an oil of 80 to 100 viscosity* is easier to emulsify than one of 30 to 40 viscosity. Hence, the latter more nearly approaches the unstable, "(juick-breaking" type of enulsion. Generally, the inert enulsifying agents, such as gums, calciun caseinate, glue, etc., at the usual concentrations, give less stable emulsions than fish-oil soaps or petroleum soaps. Everything else being equal, a reduction in the anlount of ennulsifier reduces stability.

The relative size of the globules of oil is an indication of the stability of an emulsion, and for lack of a better criterion this is used in correlating stability with efficiency. Very minute (1 micron or less), uniform globules, exhibiting pronounced Brownian movenent, indicate a very stable emulsion. But a wide range in the size of the globules (from 1 micron to 30 or 40 microns) indicates a relatively unstable emulsion. The homemade, boiled emulsion of fish-oil-soap and lubricating oil is of this latter type. Such an emulsion may be less stable than one having relatively large (10 to 15 microns), uniform droplets. Two emulsions that look iclentical under the microscope may differ in stability; one may be more stable than the other because of an excess of emulsifier, a different enulsifier, or the kind of water used for dispersion.

The properties of oil emulsions which have been found to be important and which will be discussed are:

I. Physical properties-

(1) Wetting ability of the emulsifying agent.

(2) Volatility and viscosity of the oil.

(3) Stability of the emulsion.

II. Chenical properties-

(1) Saturated oils.*

(2) Unsaturated oils.*

\section{TIIEORY OF WETTING}

Various efforts have been made to establish criteria of wetting. $\dot{\dagger}$ Robinson ('25) was unable to find a definite relation between the surface tension of the liquid and its spreading ability. Neither did he find the interfacial tension of an oil-water system to be a suitable indication. The same idea was used by Smith ('16) and by Cooper and Nuttall ('20). As there is no satisfactory technique for measuring the interfacial tension of a liquid in contact with a solid, these workers substitute a heavy oil for the solid. Measurements of this kind certainly give some indication

* See definitions, Appendix $A$.

- There are differences of opinion, especially among entomological workers, as to the distinction between wetting and spreading. Indeed, there is some doubt whether or not there is a real difference between the two phenomena. Consequently, there is no agreement as to what criterion should be used in determining the weiting ability of a spray. Woodman ('24) does not regard wetting and spreading as synonymous terms. He treats the contact-angle theory of wetting, but uses the amount of spray adhering to a glass slide as the measure of wetting. He states, however, that this is somewhit unsatisfactory. Moore ('21) and Nuttall $(20)$ also make a distinction between the two terms. But nejther of the terns is well defined, and it is difficult to separate the two ideas, even if there is a real difference between them. For practical purposes, then, it may be just as well to continue to use both terms, although there seems to be no fundamental distinction. Freundlich ('22) uses the term "spreading" in speaking of liquid-licuid systems and tne term "wetting" in speaking of liquid-solid systems, but exactly the same types of physical relations are involved in both. 
of the relative wetting ability, lut the index that is really wanted is the action of a particular spray on a particular solid. This index is expressed by the angle of contact.

The angle-of-contact theory is treated in various texthooks on physics and also by Fremullich and others of the atuhors previonsly mentioned. The discussion by Sulnen ("O(1) is particularly good.

If a drop of liquid is in contact with a solid (Fignte 1 ), three forces are involved: the surface tension of the liquicl. $T_{1} ;$ the surface tension of the solid, $\mathrm{T}_{2}$; and the interfacial tension of liquid-solid. $\mathrm{T}_{1 \%}$. The two latter, of course, are not measurable. The licjuid meets the solid at a definite angle of contact at the point $P$. The forces $T_{1}$ and $T_{12}$ tend to draw the drop into a sphere. The force $T_{2}$ is ating in the opposite direction and tends to cause the linpuid to spread out over the solid. When the liquid does not spread or does not contract. the system is in equilibrium and the forces acting in opposite directions are balanced. This is expressed by the equation, $\mathrm{T}_{2}=\mathrm{T}_{12}+$ the component of $\mathrm{T}_{1}$ which is acting in the same direction as $T_{12}$ and opposite to $T^{\prime}$. This component, by trigonometry, is $T_{1} \operatorname{Cos}(x)$ The expation for equilibrinm then becomes,

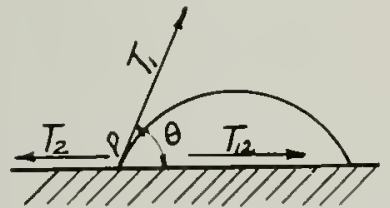

Fiti. 1. DIAgRaM of Fories THat DETERMIXE THE ARIJTY OF A LIQUUD TO WET THE STRFACE OF A Solsid.

$$
\mathrm{T}_{2}=\mathrm{T}_{12}+\mathrm{T}_{1} \cos \Theta
$$

If the equation is transposed.

$$
\operatorname{Cos} \theta=\frac{T_{12}-T_{12}}{T_{1}} .
$$

Thus it will be seen that the angle $\leftrightarrow$ is a function of all three forces. For a condition of non-wetting, the angle of contact would he $1.80^{\circ}$ and. theoretically, the drop of liquid would touch the solid at one point. For perfect wetting, the angle would be zero and the lipuicl would lie flat over the solid. Between zero and $180^{\circ}$ there is partial wetting: and the smalles the angle of contact, the greater the wetting aluility. For example, in Figure $2 A$ where the systen is in equilibrium at $60^{\circ}$. the wetting albilit $y$ is about twice as great as in Figure $2 B$, where the angle is $120^{\circ}$.

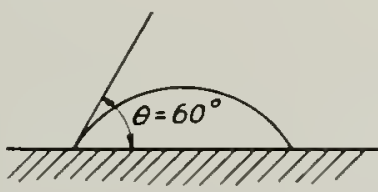

A

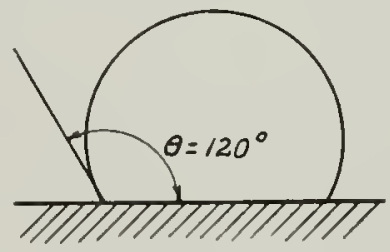

B

Fig. 2. Diagrals Coxtrastixg the Wettixg Abilites of Two Llequid. 


\section{Angle-of-Contact Measurements}

In practice it is difficult to measure the angle of contact of a drop of liquid. The force of gravity will flatten the drop somewhat; it is difficult to get drops of the same size; and the evaporation of small drops is rather rapid. Because of these difficulties it is not feasible to reflect the drop into a binocular microscope with a protractor in one barrel and measure the angle of contact. This method was tried and cliscarded for the simple method used by Stellwaag ('24).*

The apparatus is simple, and the method is quite rapid and entirely practical. The necessary pieces of equipment are: (1) a container for the liquid, (2) a device for holding the object to be tested, so that it can be turned, raised, and lowered into the liquid, and (3) a protractor etched on a mirror. For this particular work a museum jar $(8 \times 15 \times 13 \mathrm{~cm}$.) was used, and a device for holding the object was made from an old microscope stand. (See Figure 3.)

The jar should be perfectly level, and its rim should be coated with paraffin, so that the liquid will stand flush with the top or a little above it. Before testing, the surface of the liquid should be freshly cleaned with a glass rod. Leaves and other objects to be tested should not be handled, of course, and should be placed in the holder in a manner that will give as uniform a surface as possible. The liquid should be kept at a constant temperature.

As the object is slowly lowered, the liquid either will be depressed by it or will rise to it, forming a meniscus. The object is turned until the surface of the liquid is exactly horizontal at the point of contact. Then the angle of contact is read by means of the protractor, care being exercised to see that the bottom of the protractor coincides with the surface of the liquid and that the midpoint coincides with the point of intersection of the liquid by the object.

Suppose the liquid meets the leaf perpendicularily as in Figure $4 A$, the angle of contact is $90^{\circ}$. If, however, the liquid is depressed (Figure $4 B$ ). the angle is greater than $90^{\circ}$, and the leaf must be rotated to the left until the liquid meets it horizontally (Figure $4 C$ ).

The leaf should be inserted at an angle snuller than the proper angle of contact and slowly rotated until the liquid meets it on a horizontal

* So far as known, Stellwaag is the first entomologist to use the angle of contact for measuring wetting ability, and much credit is due him for pointing out the action of liquids on plant leaves of different kinds and stluctures, and the importance of wetling in the control of aphids. This method was also used by Adam and Jessop ('25) in determining the polarity of various solids.

Trappman ('26) criticizes Stellwaag's method and prefers surface tension measurements. It is quite true that the determination of the angle of contact on leaves and twigs, no two of which are exactly alike, is subject to more variability than surface tension measulements in which nothing biological is involved. Another disadvantage of Stellwagg's method is that the surface of the liquid must be kept uncontaminated. Aiso, this method is not well adapted for use with coarse suspensions. Fut it is fundamentally corlect, and, by careful and repeated observations, it affords a means of working out some of the underlying plinciples of spray practice. 


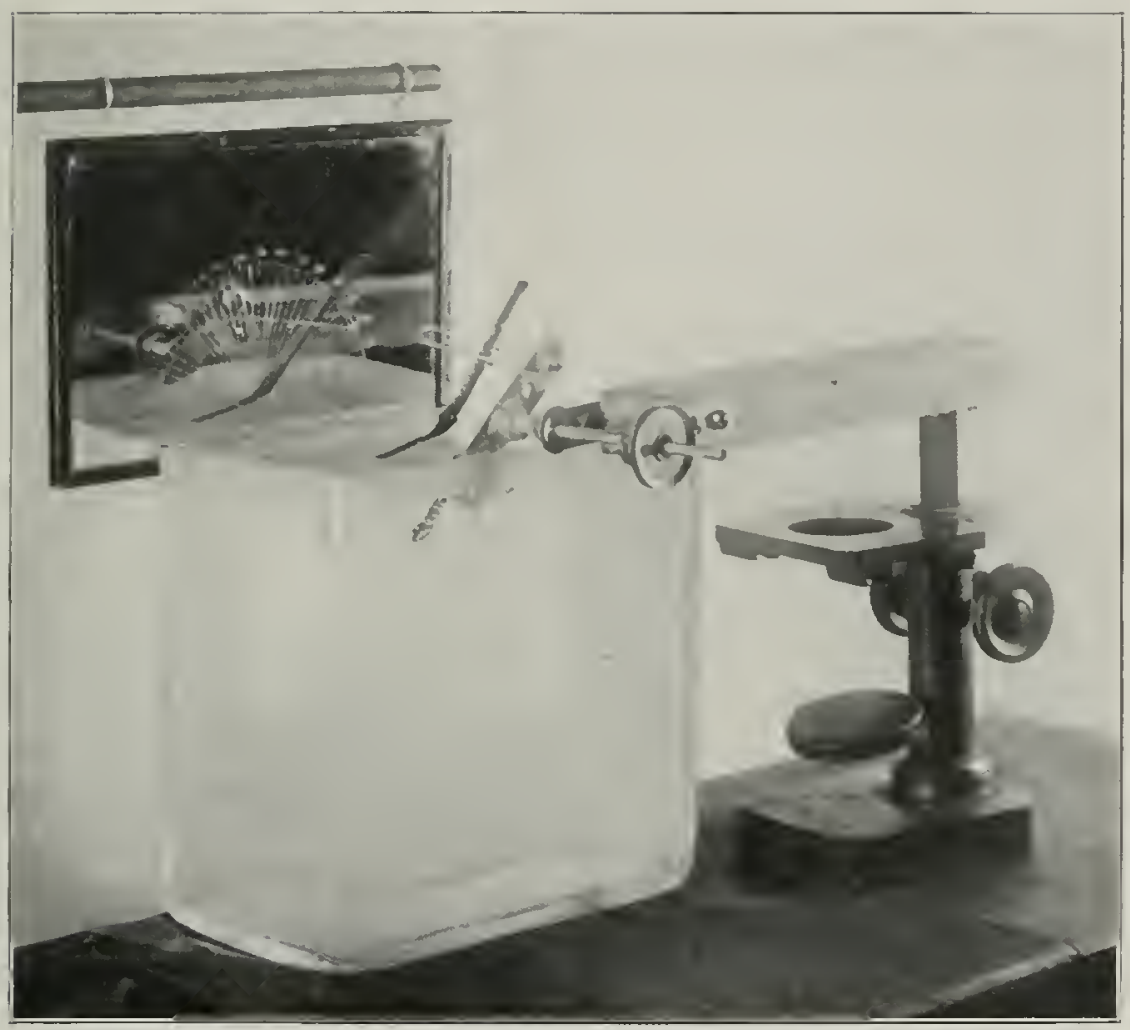

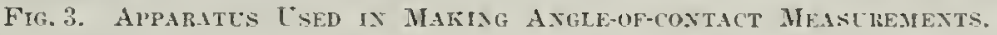

(Photo by K. F. Auden.)
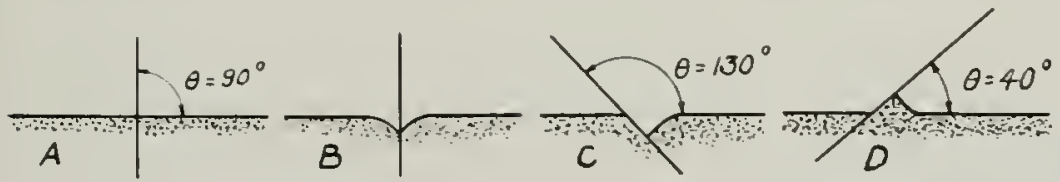

Fig. 4. DLageass Showixg Ixaertiox of a Leaf ixto Liocids at Differext Axgles ix Order to Meastre Wettixg Abllity.

In $A$, where the liquid is neither elevated nor depressed at the point of contact, the angle is $90^{\circ}$. In $B$, where the liquid is depressed, the angle of contact is greater than $90^{\circ}$. and the leaf must be rotated to the position shown in $C$. $D$ represents the position to which the leaf must be rotated when the liquid is elevated at the point of contact, the angle being less than $90^{\circ}$. 
plane. This may necessitate several trials, especially if the angle is consiclerably smaller than $90^{\circ}$. Figure $t D$ shows the position at an angle of $40^{\circ}$.

It is difficult to make angle-of-contact measurements with oil emulsions because of the very thin film of oil which persistently appears on the surface; consequently, it was thought better to make a study of the enulsifying agents that were used in several emulsions. The objects to be tested were always selected fresh, and the measurements were carried out as soon after collection as possible. The liquids were licpt at a temperature of $25^{\circ} \mathrm{C}$. throughout the tests. From three to ten observations were nuade of each object in contact with the liquids at each dilution. The dilutions ranged from 1 per cent to $1 / 16$ of one per cent. (For analysis of the water used for dilution, see $A p p c n d i . C^{-}$.)

It is not to be supposed that data thus obtained on the angles of contact represent fixed values, but they do represent relative conditions from which reliable deductions can be made.

No attempt was made to study the effect of time or repeated contact on the value of the angles. Indeed, it may be that the determinations which were made should be regarded as indications of the initial wetting ability. The hysteresis of liquid-solicl systems is a study within itself.

Figure 5 shows the results obtained in tests with corn, oat, and cabbage leaves. These leaves were chosen lecause the hair-like structures on the corn and oat leaves and the waxy covering of the cabbage leaf make them difficult to wet; and the angle-of-contact measurements for each ennulsifying agent against these three kinds of leaves were averaged in preparing the graphs of Figure 5. From these graphs it will be noted that the soaps give much lower angles than calcium caseinate or glue. This is to be expecterl, after reviewing the work of Harkins, Davies and Clark ('1i) ; for glue, calcium caseinate, and such materials are not strongly polar, and are not as readily adsorbed as soaps, nor are they thrown into an interface as easily. So far as wetting ability is concerned, the soaps are in a class by themselves, both theoretically and practically, unlcss the spray mixture is of such composition as to destroy the soap.

\section{Relation between Metting Amility \\ And Toxicity to Aphins}

That aphids are not readily killed by a spray that does not wet them. is well known. Onc of the reasons for adding soap to nicotine sulfate is to give the spray wetting abiiity. Stellwaag states that the effectiveness of a spray on aphids is almost entirely dependent on its wetting ability.

The curve for soap No. 15 in Figure 5 shows almost the same angle of contact at all the dilutions used. With potash-fish-oil soap and soap No. 5.5, the angle begins to increase quite rapidly at dilutions of $\mathrm{I} / 2$ and $\mathrm{J} / \mathrm{t}$ per cent, as these soaps begin to precipitate ont with hard water : ${ }^{*}$ and at

* See analysis of water, Appenalis $C$. 
wealier dilutions there is insufficient soap left to give good wetting. Dilution causes no appreciable change in the angle of contact with calcium caseinate and glue. The angles with these materials are not much below those obtained with water.

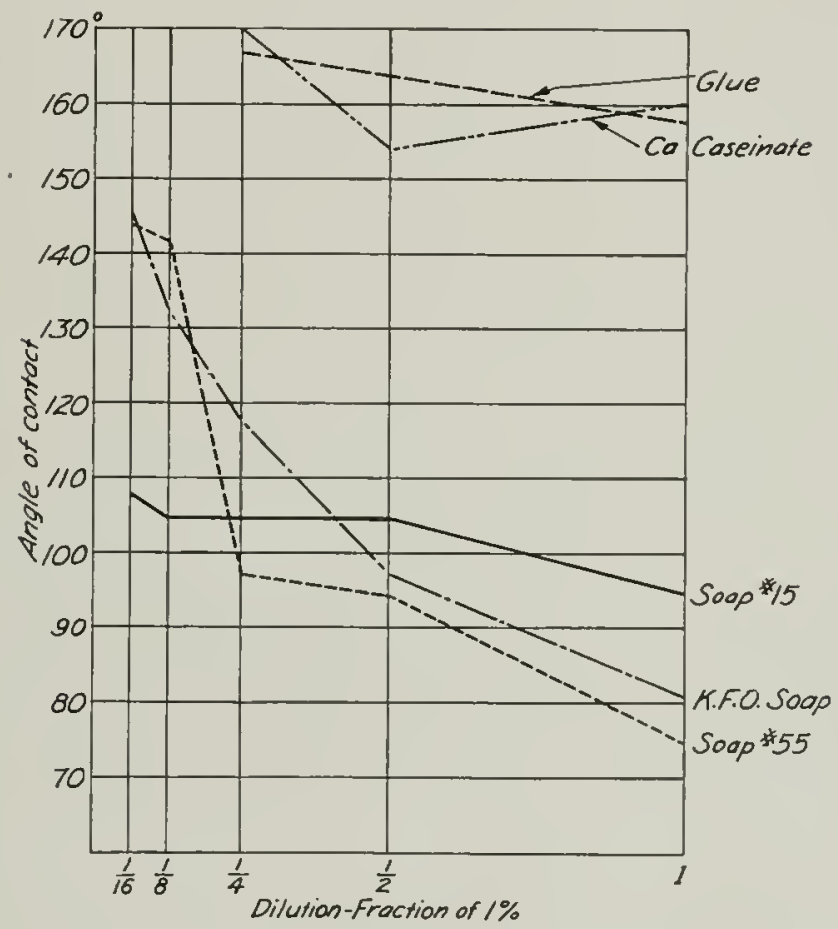

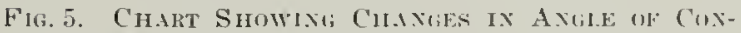

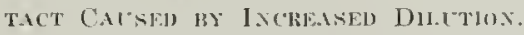

Soap No. 15 is a petrolemin product used in the preparation of soluble oils. Soap No. 55 is used for the same purpose but is made up largely of sodium oleate. FFO soap is potash-fish-oil soap.

The results of laboratory tests with three species of aphids are given in Table I. (For definitions of terms and methods of tesis, see. Ippendix $A$ and $B$.) The emulsions were diluted with tap water and were uned at a strength of :2 per cent on Hesteroncura sctariac Thos., 1 per cent on Tritogcuaphis ambrosiac Thos., and 0.5 per cent on Aphis pomi De G. Here it will be noted that stock emmlsion No. j. marle with an inert emu1sifying agent, killed a relatively low per cent of the aphirls. Homemade 
TABLE I.

Summary of 17 Tests ox Aphids, Showing the Reintive Effectivesess of Various On EMtusions.

\begin{tabular}{|c|c|c|c|c|c|}
\hline Item & Enulsion & $\begin{array}{c}\text { Emulsifying } \\
\text { agent }\end{array}$ & $\begin{array}{l}\text { Aphids } \\
\text { killed }\end{array}$ & $\begin{array}{l}\text { Aphids } \\
\text { used }\end{array}$ & $\begin{array}{l}\text { Per cent } \\
\text { killed }\end{array}$ \\
\hline $\begin{array}{l}1 \\
2 \\
3 \\
4 \\
5 \\
5 \\
6 \\
7 \\
8\end{array}$ & $\begin{array}{l}\text { Stock No. } 5 \\
\text { Homemade } \\
\text { Sol. oil No. } 56 \\
\text { Soap No. } 55 \\
\text { Soap No. 15 } \\
\text { Sol. oil No. } 90 \\
\text { Water check } \\
\text { Untreated check }\end{array}$ & $\begin{array}{l}\text { Inert }{ }^{2} \\
\text { KFO soap }{ }^{2} \\
\text { Soap No. } 55 \\
\text { Soap No. } 15\end{array}$ & $\begin{array}{r}3491 \\
3675 \\
2712 \\
3654 \\
3749 \\
4074 \\
540 \\
290\end{array}$ & $\begin{array}{l}4449 \\
4738 \\
4166 \\
4149 \\
4355 \\
4606 \\
4179 \\
4326\end{array}$ & $\begin{array}{r}78.46 \\
77.56 \\
65.09 \\
88.07 \\
86.08 \\
88.44 \\
12.92 \\
6.70\end{array}$ \\
\hline
\end{tabular}

1 Materials such as glue, calcium caseinate, and gums are classed as inert.

${ }^{2}$ KFO soap is potash-fish-oil soap.

TABI.E II.

Sumary of 5 Tests on Aphis spircecola Patchi.

Dilution of Sprays 0.5 per ceut by weight.

\begin{tabular}{|c|c|c|c|c|c|c|c|}
\hline \multirow[b]{2}{*}{ Item } & \multirow[b]{2}{*}{ Spray } & \multicolumn{3}{|c|}{ Tap water } & \multicolumn{3}{|c|}{ Distilled water } \\
\hline & & $\begin{array}{c}\text { Aphids } \\
\text { killed }\end{array}$ & $\begin{array}{c}\text { Aphids } \\
\text { used }\end{array}$ & $\begin{array}{l}\text { Per cent } \\
\text { killed }\end{array}$ & $\begin{array}{c}\text { Aphids } \\
\text { killed }\end{array}$ & $\begin{array}{c}\text { Aphids } \\
\text { used }\end{array}$ & $\begin{array}{l}\text { Per cent } \\
\text { killed }\end{array}$ \\
\hline 1 & Soap No. 15 & 770 & 999 & 77.0 & 871 & 1032 & 84.2 \\
\hline 2 & Soap No. 55 & 750 & 1068 & 70.3 & 951 & 1158 & 82.2 \\
\hline 3 & KFO Soap & 358 & 1037 & 34.6 & 761 & 1024 & 74.3 \\
\hline 4 & Ca. Caseinate & 184 & 955 & 19.3 & 157 & 968 & 16.2 \\
\hline 5 & Water Check & 61 & 997 & 6.1 & 61 & 997 & 6.1 \\
\hline
\end{tabular}

TABLe III.

Summary of 5 Tests on Aphis spiraecola Patch. Dilution of Sprays 1 per ceut by Volume.

\begin{tabular}{|c|c|c|c|c|c|c|c|}
\hline \multirow[b]{2}{*}{ Item } & \multirow[b]{2}{*}{ Spray* } & \multicolumn{3}{|c|}{ Tap water } & \multicolumn{3}{|c|}{ Distilled water } \\
\hline & & $\begin{array}{c}\text { Aphids } \\
\text { killed }\end{array}$ & $\begin{array}{l}\text { Aphids } \\
\text { used }\end{array}$ & $\begin{array}{c}\text { Per cent } \\
\text { killed }\end{array}$ & $\begin{array}{c}\text { Aphids } \\
\text { killed }\end{array}$ & $\begin{array}{c}\text { Aphids } \\
\text { used }\end{array}$ & $\begin{array}{l}\text { Per cent } \\
\text { killed }\end{array}$ \\
\hline 1 & Sol. Oil No. 90 & 1254 & 1346 & 93.3 & 854 & 1007 & 84.9 \\
\hline 2 & Sol Oil No. 17 & 1194 & 1239 & 96.4 & 924 & 1057 & 87.3 \\
\hline 3 & Sol. Oil No. 56 & 816 & 1046 & 78.3 & 657 & 962 & 68.3 \\
\hline 4 & Stock No. S15 & 748 & 980 & 76.3 & 645 & 989 & 65.3 \\
\hline 5 & Stock No. 5 & 581 & 991 & 58.6 & 367 & S03 & 45.7 \\
\hline 6 & Water Check & 129 & 817 & 15.8 & 129 & 817 & 15.8 \\
\hline
\end{tabular}

* Soluble oils Nos. 90 and 17 are emulsified with soap No. 15 ; soluble oil No. 56 , with soap No. 55; stock emulsion No. S15, with potash-fish-oil soap; and stock emulsion No. 5, with a material similar to calcium caseinate. 
emulsion and soluble oil No. $5 f$, which are made with soaps that precipitate out with hard water, also show inefficiency.

It is ruite striking that soluble oil No. 56 shows a kill of only 6i. per cent, while its emulsifying agent (Soap No. 55), alone, shows a kill of so per cent. Soluble oil No. 56 consists of about 20 per cent of soap No. 55 and so per cent oil: hence, the spray contains only one-fiftl as much soap as No. 5i) at the same dilutions. From Figure it it will be seen that soap No. 5is at a dilution of 1 per cent still shows a low angle of contact. But soluble oil No. sti, being so much weaker, has soap precipitated from it quite rapidly and, hence, is low in wetting ability. Soap No. 15, by contrast. does not precipitate ont so reaclily, and its soluble oils maintain their efficiency.

In view of the fact that fish-oil soap and soap No. i.) precipitate out in hard water, it would be logical to predict a higher per cent kill if these soaps were dispersed in distilled water insteal of tap water. This prediction is borne out by Table II. W"hile there are varying increases with all of the soaps, the increase from : 4.6 per cent to $: 3.3$ per cent with fish-oil soap is particularly noteworthy. Calcium caseinate shows rery little difference, as would he expected.

Since the soaps are more effective with rlistilled water, it seems that the emulsions made from them should be nore effective. This, however, is not true, as will be seen in Table 1I1, where the per cent kill for distilled water is in no case higher than the pes cent kill for tap water. Here the effect of the water on the type of emulsion is introrluced. If tap water precipitates out some of the soap, an emmlsion dispersed in it naturally is not as stable as one dispersed in distilled water. With the exception of entulsion No. S15 there is very little difference in stability of those diluted with tap water and those diluted with distilled water, as determined ly centrifuging. There is no perceptible difference in the size of the globules of the tap water enulsions and the listilled water entulsions. If, however, the dilnted emulsions are allowed to stand in cylinders for a few days, those made with tap water show a distinct separation of oil. Soluble oil No. 90 is very stable, and the difference in stability with tap and distilled water is insufficient to be preceptible in a plotograph. If drops of the emulsions are compared unler a binocular microscope. those diluted with tap water seem to have more oil at the surface of the drop than the corresponding emulsions cliluted with distilled water. This adsorption of oil may be a factor in the wetting of aphicls and the retention of spray by then. Drops of a poor wetting spray bonnce off the aphids, and very little is retained. Much additional work is needed to clear up the relation of wetting ability and stability to the possible concentration of the oil on plants and insects. 


\section{Relition of Chemical Property of Oll ind Stability of EuUlsion \\ TO EFFECTIVNESS IGANST AIIIIDS}

The kind of oil and the amount of emulsifying agent in an emulsion produce differences in efficiency, as shown in Table IV. (See Figure ij.) The emulsions under items 1 and 2 in this table are relatively ineffective. These emulsions are of the quick-breaking type, hut they do not have the necessary wetting ability. The emulsions monder items $3,4,5$, and 6 have the necessary wetting ability, but vary in stability. Soluble oil No. 18, an extremely stable emulsion, the globules of which cannot be seen with the ordinary high power of the microscope, is the least effective of these four. its per cent kill being only 86.8. Soluble oil No. 9(), the globules of which can barely be seen in the photograph. gives a kill of 88.4 per cent. When the amount of emulsifying agent is reduced as in No. 1\%, making a less slable enulsion, the kill is 94.6 per cent. Soluble oil No. 16 has the same amount of emulsifying agent as $\mathrm{No}$. 90, but it is made from a saturated oil, which in this case gives an emulsion having about the same stability as No. 1i, and the kill is in very good agreement. That emulsions having clobules of different sizes would have different properties was indicated by Mloore ('23), and the size of globules has been correlated with toxicity to aphids in recent work by Griffin, Richardson, and Burdette ('2\%).

As to instability, this theory is offered: The less stable the emulsion. the greater the amount of oil thrown to the surface of the spray drops, or adsorbed by them: and a very unstable enulsion thus approaches a water-in-oil type of spray, with a consequent increase in the amount of oil adhering to the plant or insect.

The chemical difference between the saturated and unsaturated oils in these emulsions appears to be of minor importance. The dominating factors are the wetting ability and the instability of the emulsion. The experimental data indicate that the most effective emulsion on aphids

TABLE IV.

Staldali on Tests ox THIEE Slecies of Aphids (T. ambrosine. H. sctarine, ixd

1. pomi), Showixg Inflexce of Chealcal Property of Oil axd Staibity of EaIULSIOx.

\begin{tabular}{|c|c|c|c|c|c|c|c|}
\hline \multirow{2}{*}{ Item } & \multirow{2}{*}{ Emulsion } & \multirow{2}{*}{ Oil } & \multicolumn{2}{|c|}{ Emulsifying agent } & \multirow{2}{*}{$\begin{array}{c}\text { Aphids } \\
\text { killed }\end{array}$} & \multirow{2}{*}{$\begin{array}{l}\text { Aphids } \\
\text { used }\end{array}$} & \multirow{2}{*}{$\begin{array}{l}\text { Per cent } \\
\text { killed }\end{array}$} \\
\hline & & & Kind & Amount & & & \\
\hline 1 & Stock No. 5 & Sat. ${ }^{1}$ & Inert. & Reduced & 3491 & $\$ 449$ & 78.46 \\
\hline 2 & Homemade & Unsat." & I.F.O. Soap & Nornual & 3675 & 4738 & 77.56 \\
\hline 3 & Sol. Oil No. 18 & Unsat. & Soap No. 15 & Excess & 4300 & 4952 & 86.83 \\
\hline 4 & Sol. Oil No. 90 & Unsat. & Soap No. 15 & Norma] & 4074 & 4606 & SS.44 \\
\hline 5 & Sol Oil No. 17 & Unsat. & Soap No. 15 & Reduced & 4721 & 4986 & 94.68 \\
\hline 6 & Sol. Oil No. 16 & Sat. & Soap No. 15 & Normal & 4837 & 5174 & 93.48 \\
\hline 7 & Water Check & & & & 540 & 4179 & 12.92 \\
\hline S & Untreated Check & & & & 290 & 4326 & 6.70 \\
\hline
\end{tabular}

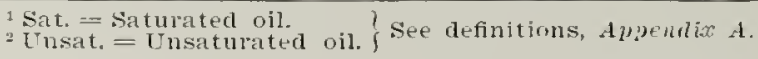




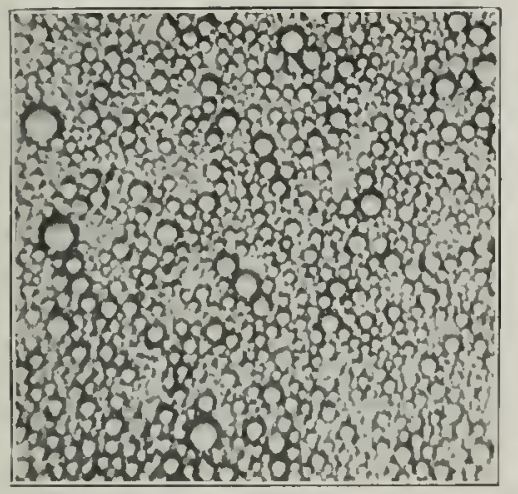

1. Stock emulsion No. 5 .

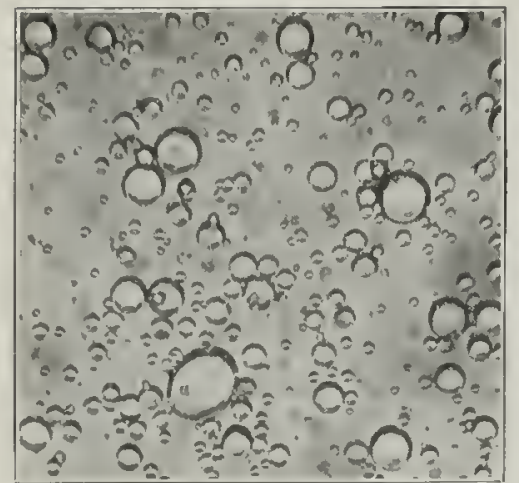

b. Homemade lubricating.oil emul. sion.

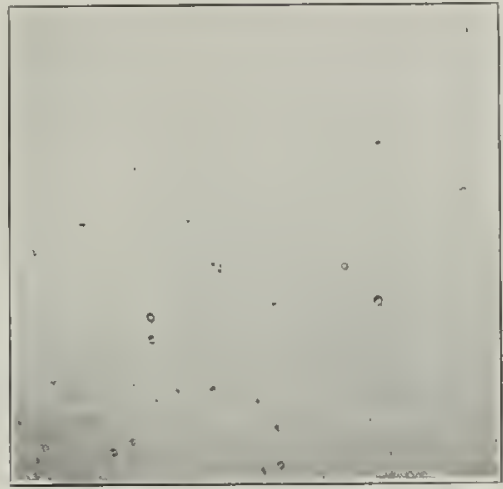

c. Soluble oil No. 90.

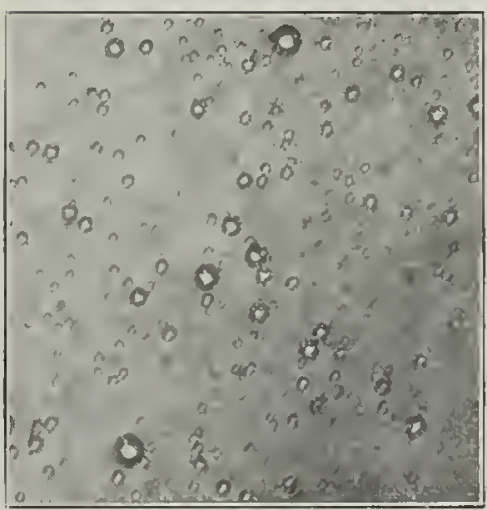

D. Soluble oil No. 17.

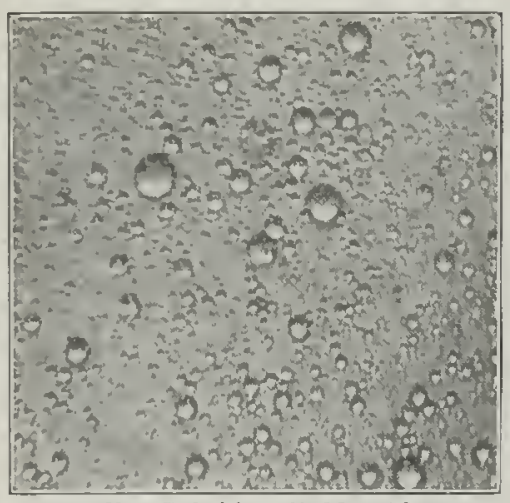

b. Soluble oil No. 16.

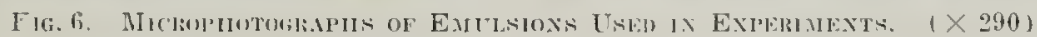


would be one that is relatively unstable and has high wetting ability. But anlagonistic factors are encountered; for the emulsions that have high wetting ability are injurious to foliage, and chemically inert emulsions do not have high wetting ability.

\section{Relation between Wetting Ability and Toxicity to Sax Jose and Orster-shell Scale (in the Dormant Stage)}

Good wetting ability, which was shown to be an important requisite of enulsions for use on aphids (Table I), is not so important in the case of oyster-shell scale and San Jose scale. In this case, the emulsions that certainly have poor wetting ability are just as effective as those having good wetting ability. This can be seen $f$ rom a series of laboratory experiments on oyster-shell scale* (Table V) and a typical field test on San Jose scale* (Table VI). It is not necessary to discuss this point at length or to present a great many data, for similar results have been obtained by

TABLE $V$.

Sumadry of Tests ox Oyster-shell Scale, Showtyg Ixfluence of WETTING ABILITY.

\begin{tabular}{|c|c|c|c|c|c|c|}
\hline \multirow{2}{*}{ Item } & \multirow{2}{*}{ Emulsion } & \multirow{2}{*}{$\begin{array}{c}\text { Emulsifying } \\
\text { agent }\end{array}$} & \multicolumn{4}{|c|}{ "Per cent killed at dilution of } \\
\hline & & & $5 \%$ & $10 \%$ & $10 \%$ & $10 \%$ \\
\hline 1 & Stock Emul. No. S 15 & K. F. O. Soap & 36.3 & 99.4 & 99.8 & 97.3 \\
\hline 2 & Stock Emul. No. 5 & Inert & 96.2 & 90.9 & 99.8 & 99.5 \\
\hline 3 & Soluble Oil No. 17 & Soap No. 15 & 47.3 & 93.3 & 99.4 & 99.5 \\
\hline 4 & Soluble Oil No. 90 & Soap No. 15 & 41.7 & 92.8 & & 96.4 \\
\hline 5 & Checks & & 0.0 & 0.0 & 0.0 & 0.0 \\
\hline
\end{tabular}

* Check basis,

TABLE V1.

Sumarit of Tests ox San Jose Scale, Silowing Ixfluence of WeTtiNg ABILITY.

\begin{tabular}{|c|c|c|c|c|}
\hline \multirow{2}{*}{ Item } & \multirow{2}{*}{ Enulsion } & \multirow{2}{*}{$\begin{array}{c}\text { Emulsifying } \\
\text { agent }\end{array}$} & \multicolumn{2}{|c|}{ Per cent live scale } \\
\hline & & & $2 \%$ solution & $1 \%$ solution \\
\hline $\begin{array}{l}1 \\
2 \\
3 \\
4 \\
5\end{array}$ & $\begin{array}{l}\text { Stock Emul. No. S } 15 \\
\text { Stock Emul. No. } 5 \\
\text { Soluble Oil No. } 16 \\
\text { Soluble Oil No. } 90 \\
\text { Checks }\end{array}$ & $\begin{array}{l}\text { K. F. O. Soap } \\
\text { Inert } \\
\text { Soap No. } 15 \\
\text { Soap No. } 15\end{array}$ & $\begin{array}{r}2.4 \\
3.0 \\
0.2 \\
7.7 \\
66.6\end{array}$ & $\begin{array}{r}5.9 \\
7.4 \\
4.7 \\
28.5 \\
66.6\end{array}$ \\
\hline
\end{tabular}

\footnotetext{
* For methods, see Appendix $B$.
} 
TAIREE VI1.

Axgles of Coxtact (Meas Vales), Showixg Reintive Ease of Wettixg VARIOLS LEATES AND TWIiss.

\begin{tabular}{|c|c|c|c|}
\hline \multirow{2}{*}{ Object } & \multicolumn{3}{|c|}{ Liquid } \\
\hline & K. F, O. soap & Glue & Tap water \\
\hline $\begin{array}{l}\text { Oat Leaf-Upper side } \\
\text { Corn leaf-Upper side } \\
\text { Cabbage leaf-Upper side } \\
\text { Apple skin--Ben Davis (Green) } \\
\text { Apple leaf-Upper side (Jonathan) } \\
\text { Peach leaf-Upper side (Elberta) } \\
\text { Apple twig-(Jonathau)* } \\
\text { Peach twig-(Elberta)* } \\
\text { Poplar twig** } \\
\text { Lilac twig*t. }\end{array}$ & $\begin{array}{r}113 \\
126 \\
104 \\
89 \\
44 \\
35 \\
27 \\
45\end{array}$ & $\begin{array}{r}171 \\
175 \\
127 \\
107 \\
64 \\
65 \\
41 \\
50\end{array}$ & $\begin{array}{r}180 \\
180 \\
167 \\
130 \\
55 \\
60 \\
40 \\
50 \\
5 \\
0\end{array}$ \\
\hline
\end{tabular}

* Inimant.

† Intrusted with oyster-shell scale.

Chandler, Flint and Huber ( 206$)$ on San Jose scale:* by List ('?t) on oyster-shell scale; and by Flint and Bigger $(: 26)$. Hawley $(: 26)$. Wakeland ( 25 ), and Melander ( 21 ) on the fruit tree leaf roller.

There are two reasons why these insects are controlled by oil emulsions that do not necessarily have high wetting aluility:

(1) Apple, peach, poplar, and lilac twigs are not difficult to wet, as is shown in Table VII. Tap water wots them rather easily. This, by the way, may he responsible for a higher "runoff" with "good-wetting" sprays than with sprays of poor wetting ability, as is indicated in deOng"s (26) figures showing an increase in the amount of oil in the "runoff" with an increase in the amount of ennulsifying agent. With other sprays Ruth and Kelley ('?2) show, by weighing, that the amount of spray retained will vary with both the surface sprayed and the spray ned.

(2) In comparing the effect on aphicls with that on scales, it should be considered that scales are sesile, while aphids are not. Aphids become (1uite active when disturbed by spraying. and they have been observed to crawl out of a drop of liquid or to rid themselies of a globule lyg moving around. This, of course. applics only to sprays that do not wet then.

Therefore, wetting ability is not an important factor in the control of San Jose scale, oyster-shell scale, and apparently leat-roller eggs, for the simple reason that the host plants, being easily wetted, retain sufficient spray to insure an oil film coverage as soon as the enulsion breaks. From the results of deOng ( 27 ), Yothers ('24), and 11 oglum (25). it seems that the same principle holds for citrus scales.

* In a private communication, B. A. Porter reputs similar results. 


\section{Relation of Volatility axi Viscosity of Oil to Effectiveness against Scale lnsects.}

The theory formulated by deong from his work on citrus scales may le applied also to oyster-shell and San Jose scales. The data in Table YIII demonstrate that a spray containing an oil of 60 viscosity and 5.3 per cent volatility is not as effective against oyster-shell scale as a corresponding spray containing an oil of slightly higher viscosity and lower volatility. Likewise, a refuned kerosene of 32 viscosity and 35.1 per cent volatility, emt1sified with potash-fish-oil soap, is very ineffective. If the toxicity were due to penetration alone, a light oil of this nature should be more effective than heavier oils. With this in mind, a series of laboratory tests were run witl oyster-shell scale to determine the action of unemulsified, or "straight", oils on the scale (Table $\mathrm{K}$ ). Neither the refined nor the umrefined lierosene was effective. Oil No. 31, of 60 viscosity and 5.3 per cent volatility, which was rum as a check, gave practically a perfect

TABIE VIII.

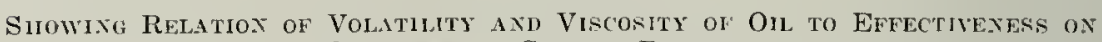
OYSTER-SHELL SCALE.-DOLMANT.

\begin{tabular}{|c|c|c|c|c|c|c|c|}
\hline \multirow{3}{*}{ Iten } & \multirow{3}{*}{ Emulsion } & \multirow{3}{*}{$\begin{array}{c}\text { Emulsifying } \\
\text { Agent }\end{array}$} & \multicolumn{3}{|c|}{ Properties of the oil } & \multirow{2}{*}{\multicolumn{2}{|c|}{$\begin{array}{l}\text { Per cent } \\
\text { killed at dilu. } \\
\text { tion of }\end{array}$}} \\
\hline & & & \multirow{2}{*}{ Kind } & \multirow{2}{*}{$\begin{array}{l}\text { Viscos- } \\
\text { ity } \\
\text { Ser. }\end{array}$} & \multirow{2}{*}{$\begin{array}{l}\text { Vola- } \\
\text { tility } \\
\text { Per } \\
\text { cent }\end{array}$} & & \\
\hline & & & & & & $5 \%$ & $10 \%$ \\
\hline 1 & Soluble Oil No. 34 & Soap No. 37 & Sat. & 60 & 5.3 & 0.0 & 74.1 \\
\hline 2 & Soluble Oil No. 35 & Soap No. 37 & Unsat. & 83 & 1.0 & 38.7 & $\$ 6.4$ \\
\hline 3 & Soluble Oil No. 33 & Soap No. 37 & Sat. & 83 & 1.0 & 69.6 & 94.1 \\
\hline 4 & Stock Emul. No. S 7 & K. F. O. Soap & Sat. & 32 & 35.1 & & 13.5 \\
\hline 5 & Stock Emul. No.S 8 & K. F. O. Soap & Sat. & 60 & 5.3 & 6.0 & 90.8 \\
\hline 6 & Stock Emul. No. S 9 & K. F. O. Soap & Sat. & S3 & 1.0 & 9.6 & 99.9 \\
\hline 7 & Stock Emul. No. S10 & K. F. O. Soap & Unsat. & 104 & 0.2 & 36.3 & 99.4 \\
\hline$\$$ & Checks & & & & & 0.0 & 0.0 \\
\hline
\end{tabular}

TAISE IX.

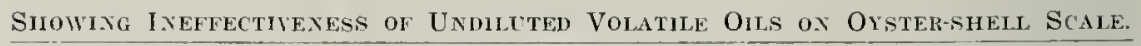

\begin{tabular}{|c|c|c|c|c|c|c|c|}
\hline \multirow[b]{2}{*}{ Item } & \multirow[b]{2}{*}{ Oil } & \multicolumn{3}{|c|}{ Propertics of the oil } & \multicolumn{3}{|c|}{ Per cent killed } \\
\hline & & lind & $\begin{array}{c}\text { Viscos- } \\
\text { ity }\end{array}$ & $\begin{array}{l}\text { Vola- } \\
\text { tility }\end{array}$ & A & $\mathrm{B}$ & $\mathrm{C}$ \\
\hline 1 & Refined No. 9 & Sat. & 32 & 35.10 & 9.0 & 4.0 & 52.7 \\
\hline 2 & $\begin{array}{l}\text { Perfection Kero- } \\
\text { sene }\end{array}$ & Unsat. & 32 & 54.28 & & 41.7 & 67.7 \\
\hline 3 & Oil No. 31 & Sat. & 60 & 5.30 & & & 99.9 \\
\hline 4 & Checks & & & & 0.0 & 0.0 & 0.0 \\
\hline
\end{tabular}


kill. In hour or two after twigs are treater with these light oils, there is no evidence of oil present: whereas a distinct resirlue of the heavier oil persists for a week or more. Inalogous results were obtained on San Jose scale, ats will be seen from Table $X$. The light oil of high volatility was not effective when emulsified with fish-oil soaj or with an inert agent or when incorporated in a soluble oil.

There may be a wide range of viscosity (from so wp to ?.50 or :3011) withont any appreciable change in volatility. When the viscosity drops as low as bo, there is a rise in volatility and a decrease in effectiveness. It is belicved that a suitable oil for seale control should not fall helow st viscosity and should not have a volatility of over l per cent.

TA1:LI: X.*

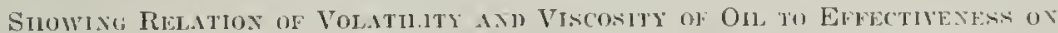
SAX JosE SGAIE.

\begin{tabular}{|c|c|c|c|c|c|c|c|c|}
\hline \multirow{3}{*}{ Iteml } & \multirow{3}{*}{ Emulsion } & \multirow{3}{*}{$\begin{array}{l}\text { Emulsity - } \\
\text { ing agent }\end{array}$} & \multicolumn{3}{|c|}{ Properties of the oil } & \multirow{2}{*}{\multicolumn{3}{|c|}{$\begin{array}{l}\text { Per cent live seale } \\
\text { at dilution of }\end{array}$}} \\
\hline & & & \multirow{2}{*}{ kind } & \multirow{2}{*}{$\begin{array}{c}\text { Viscos- } \\
\text { ity } \\
\text { sire. }\end{array}$} & \multirow{2}{*}{$\begin{array}{l}\text { Vola- } \\
\text { tility } \\
\text { Prer } \\
\text { rent }\end{array}$} & & & \\
\hline & & & & & & $3 \%$ & $2 \%$ & $1 \%$ \\
\hline 1 & Stock Emulsion & K.F.O. Soap & l'usat. & 104 & 0.19 & 0.9 & & \\
\hline 2 & Stock Emulsion & K.F.O. Soap & Sat. & 8.3 & 1.00 & (1). 2 & & \\
\hline 3 & Stock Emulsion & K F.O. Soal & Sat. & 32 & 35.10 & 36.2 & & \\
\hline 4 & Stock Enulsion & Inert & ITnsat. & 104 & 0.19 & 2.0 & & \\
\hline 5 & Stock Emulsion & Inert & Sat. & $8: 3$ & 1.011 & 0.2 & & \\
\hline 6 & Stock Emulsion & Inelt & Sat. & $3 \ddot{2}$ & $\$ 3.10$ & 11.6 & & \\
\hline 7 & Soluble Oil No. 56 & Soall No. 55 & linsat. & $8: 3$ & 1.07 & & 4.5 & 27.7 \\
\hline$\dot{s}$ & Soluble Oil No. 47 & Soap No. 55 & Sat. & 32 & 35.10 & & $2 t .3$ & 35.6 \\
\hline 9 & Checks & & & & & $4: 3.0$ & 66.6 & 66.6 \\
\hline
\end{tabular}

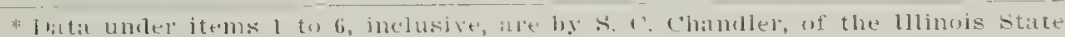
Nitur:ll llistory survey.

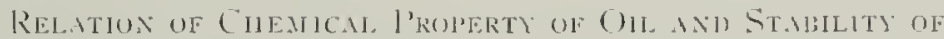

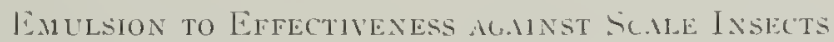

Data in some of the precerling tables suggest differences in the effectiveness of saturated and unsaturated oils on scale insects. With a slight repetition of some of the data an attempt will be made to demonstrate these differences.

Table X1 show's data on oyster-shell scale oltaned with the enulsions shown in the photographs of Figure $?$. The first two emulsions listed here have the sane oil content, and the emmlsifying agent in both is a potash-petroleum soaj, but No. 35 contans an misatninated oil and No. 3:3 at saturated oil. The latter, being a quicker-breaking emulsion, gave a higher per cent liill than No. :5.). Soluj)le oils Nos. 1 (i and t.j (items :? and t in Table XI) are made from the same oil, but No. ti, having to per 
cent less emulsifying agent than No. 16 , is a very unstable emulsion, and the difference in kill at a dilution of 5 per cent is very striking: 97.6 per cent kill for the unstable emulsion against 26.3 per cent for the stalsle one. Nos. S9 and $\$ 10$, although made from different oils, are both ruickbreaking emulsions. Here, apparently, the unsaturated oil seems to be slightly more effective than the saturated oil. If reference is made to Table IX, showing the toxicity of undiluted volatile oils to oyster-shell scale, it will be noted that the saturated oil gave kills of 4.0 per cent and $52 . \%$ per cent in two separate experiments, whereas the unsaturated oil gave kills of $41 . \%$ per cent and $6 \% . \%$ per cent in the same experiments. The data uncler items 5 and 6 in Table XI also indicate that the unsaturated

TAIRE XI.

Silowixg Relation of Cinfical Property of Oil axd Stabllity of Emeisiox to EfFectiveness on Orster-shell Scale.

\begin{tabular}{|c|c|c|c|c|c|c|c|c|}
\hline \multirow{3}{*}{ Item } & \multirow{3}{*}{ Emulsion } & \multirow{3}{*}{$\begin{array}{l}\text { Emulsify- } \\
\text { ing agent }\end{array}$} & \multicolumn{4}{|c|}{ Properties of the oil } & \multirow{2}{*}{\multicolumn{2}{|c|}{$\begin{array}{l}\text { Per cent } \\
\text { killed at } \\
\text { dilution of }\end{array}$}} \\
\hline & & & \multirow{2}{*}{ Kind } & \multirow{2}{*}{$\begin{array}{c}\text { Loss } \\
\text { to } \\
\mathrm{H}_{\mathrm{sO}}, \\
\mathrm{Per} \\
\text { cent }\end{array}$} & \multirow{2}{*}{$\begin{array}{l}\text { Vis- } \\
\text { cosity } \\
\text { Sec. }\end{array}$} & \multirow{2}{*}{$\begin{array}{l}\text { Vola- } \\
\text { tility } \\
\text { Per } \\
\text { cent }\end{array}$} & & \\
\hline & & & & & & & $5 \%$ & $10 \%$ \\
\hline 1 & Soluble Oil No. 35 & Soap No. 37 & Unsat. & 9.0 & 83 & 1.0 & 38.7 & 86.4 \\
\hline 2 & Soluble Oil No. 33 & Soap No. 37 & Sat. & 1.0 & 83 & & 69.6 & 94.1 \\
\hline 3 & Soluble Oil No. 16 & Soap No. 15 & Sat. & 0.0 & 83 & 0.2 & 26.3 & 98.9 \\
\hline 4 & Soluble Oil No. 45 & Soap No. 15 & Sat. & 0.0 & 83 & 0.2 & 97.7 & 99.8 \\
\hline 5 & $\begin{array}{l}\text { Stock Emulsion } \\
\text { No. S } 9\end{array}$ & K.F.O. Soap & Sat. & 1.0 & $\$ 3$ & 1.0 & 9.6 & 99.9 \\
\hline 6 & $\begin{array}{l}\text { Stock Emulsion } \\
\text { No. S } 10\end{array}$ & K.F.O. Soap & Unsat. & 7.0 & 104 & 0.2 & 36.3 & 99.4 \\
\hline 7 & Checks & & & & & & 0.0 & 0.0 \\
\hline
\end{tabular}

oil is slightly more efiective. Thus, the unsaturated oil may be more effective if the enulsion is quick-breaking; otherwise, the saturated oil may be more effective because of its influence on stability.

The influence that saturated and unsaturated oils may have on the stability of an emulsion, together with their relative effectiveness, is further indicated by the results on San Jose scale shown in Table XII. (See Figure 8.) Soluble oils Nos. 90 and 16 are made from equal amounts of the same emulsifying agent, but No. 90 is the more stable, probably on account of the fact that the oil from which it is made is not so highly refined as the oil in No. 16. It will be seen that No. 90 is relatively less efficient on San Jose scale on peach, as well as on apple. Soluble oil No. 17 made with the same oil as No. 90 , but with a reduced amount of emulsifier, is relatively more effective. The influence that saturated and unsaturated oils may have on the stability of the emulsion and its effectiveness is indicated to a slight extent when the oils are emulsified with an inert material. It will be noted from the photographs in Figure 8 that stock emulsion No. 210 is sligintly more stable than No. 200. 


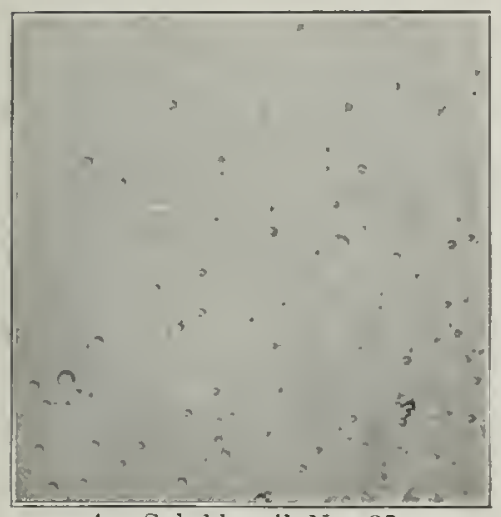

A. Soluble oil No. 35 .

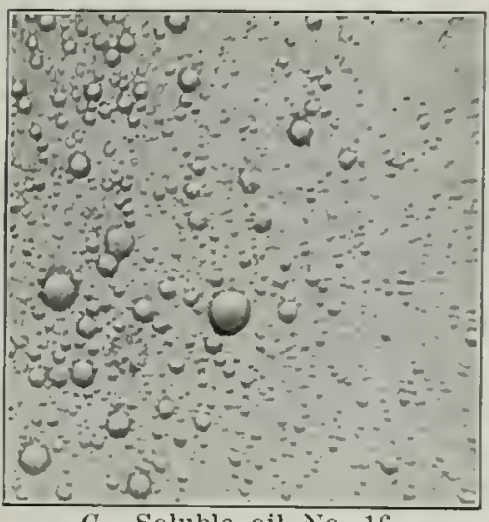

C. Soluble oil No. 16.

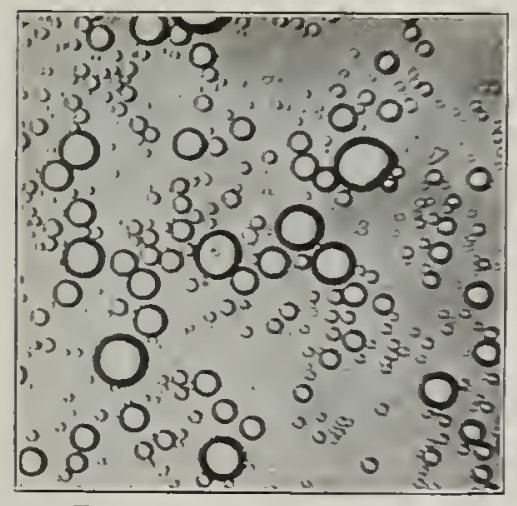

E. Stock emulsion No. S9.
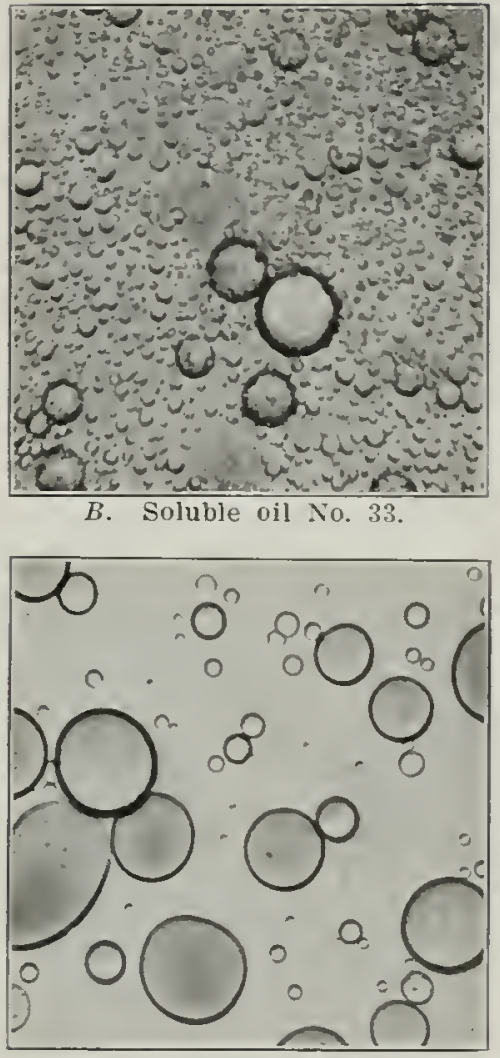

D. Soluble oil No. 45 .

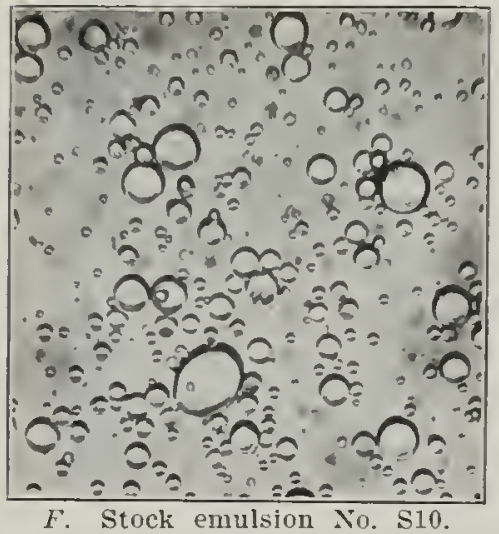

Fig. 7. MIClophotogliAmis of EMtLsioxs USED IX ExpERIExts, $(\times 290)$ 


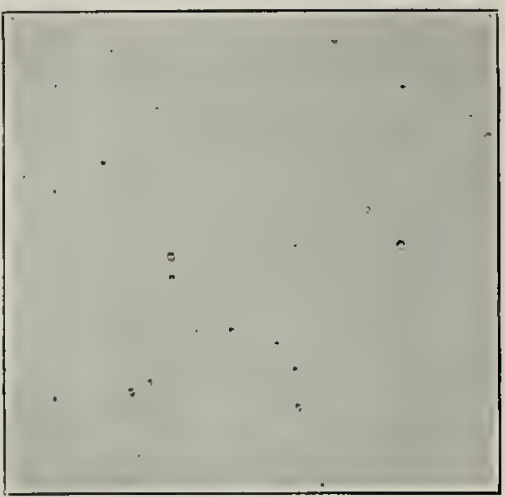

A. Soluble oil No. 90 .

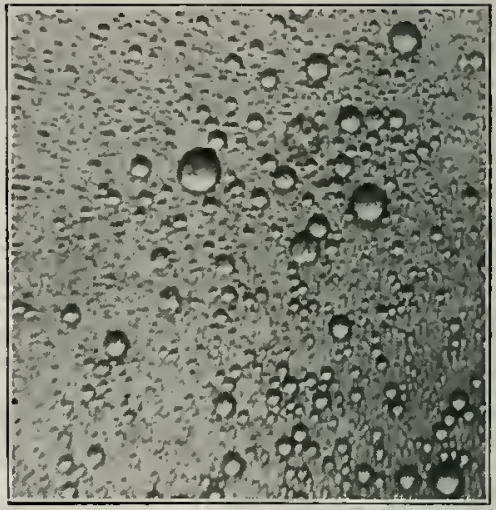

B. Soluble oil No. 16

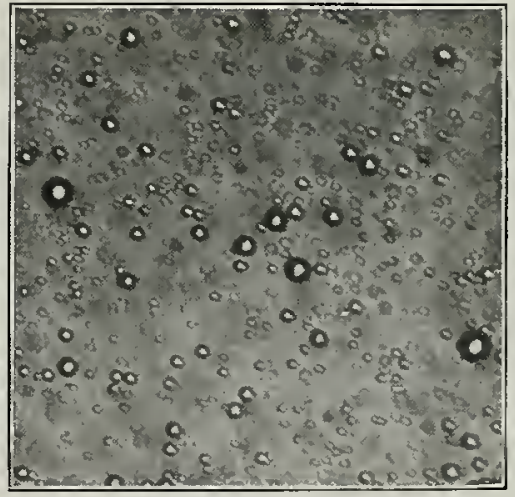

C. Soluble oil No. 17 .

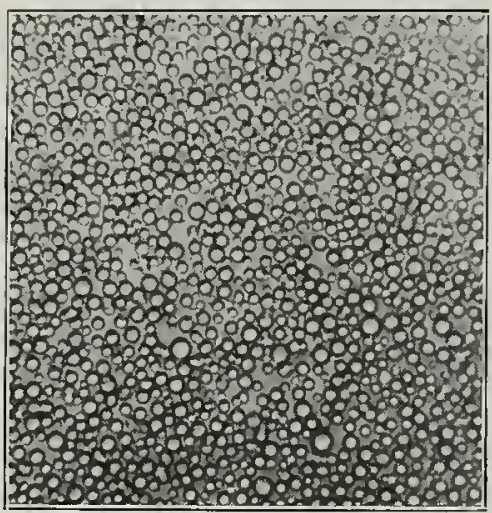

D. Stock emulsion No. 210.

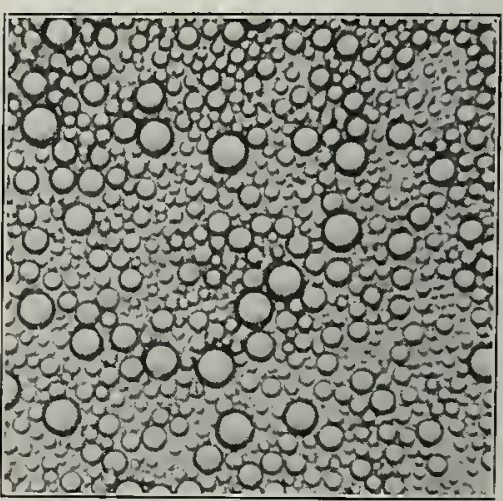

E. Stock emulsion No. 200.

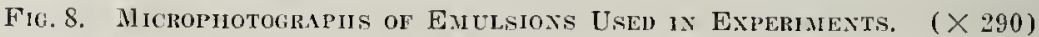


The results on scale insects corruborate deOng: work by indicating that the action of an oil enulsion in producing death is largely a physical one. cansing suffocation. If the action is dite to pentetration alone, then the oils of low viscosity should be more effective, because of their greater mobility. But high volatility is usually associated with low vincosity, and if cleath is $t$, be effected by penetration. the oil shottd persist. The ineffectireness of light volatile oils has been demonstrated by Noore and Graham ("1s), who state that such oils may eraporate too quickly to cattse

T.MBLE XII.

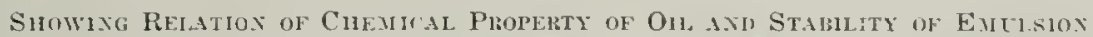
to EFFrotiveyess ox SAx Jose Scala.

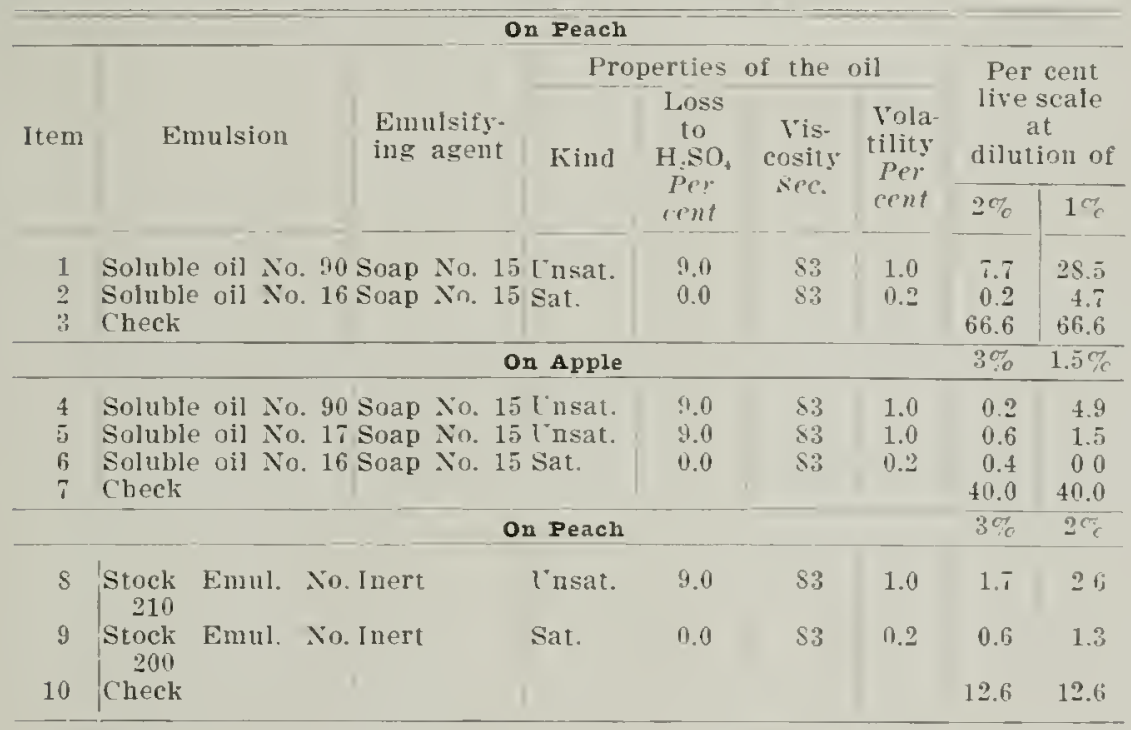

Note: Emulsifying agent in sol. oil Nos, $t \bar{i}$ reduced.

death. It las been observed by def $11 \mathrm{~g}$ (":i) that scale insects may actwally expel the lighter oils from their tracheal systems. If the action were mainly chemicat, the musturater oils, which are more active chenically: would be more effective. The important point in scale control is to apply an emulsion that will release quicliy an oil of sufficiently high viscosity and low volatility to give a residue that will persist for sometime.

\section{IN J JRR TU PLANTS}

As a general rule, the higher the visconity and the lower the rolatility of an oil. the more likely it is to cause injury to plants, whether it is sattuated or unsaturaterl. it is quite possille to apply a rolatile, unsaturated kerosene without much danger of injury, but with oils that give a persistent residue it is necessary to increase the degree of refinement in 
order to insure safety to foliage. Wherever a persistent residue is required, therefore, the difference between saturated and unsaturated oils is the most important consideration with respect to plant injury.

In tests on apple foliage it has not been found necessary to use an oil of medicinal quality, i. e., an oil that shows no loss to 97 per cent sulfuric acid. An oil having a loss of 1 per cent to sulfuric acid and a viscosity of 83 has been found quite safe on apple foliage at dilutions as high as 4 per cent when emulsified with some inert material. But the incorporation of a saturated oil, even of medicinal quality, in a soluble oil did not prove safe, nor did it apparently decrease the injury below that of the corresponding unsaturated oil. Although the saturated oil itself and the petroleum soap were relatively innocuous when applied separately, a safe combination of the two could not be worked out. Replacing sodium with potassium in the soap did not reduce injury; neither did an entire change of emulsifying agent. The incorporation of a highly volatile saturated oil in a soluble oil did reduce injury considerably, but the combination was not entirely safe and was not of satisfactory insecticidal efficiency. (Tables VIII, IX, X.)

In the early stages of the work, various oils were applied undiluted, or "straight", to apple twigs in order to deternine their liability to cause injury. The results of a typical test are seen in Table XIII.

TABLE XIII.

InJURy to APPLe Foliage by UNdiluted Oils.

\begin{tabular}{|c|c|c|c|c|c|c|c|c|c|}
\hline \multirow{2}{*}{ Item } & \multirow{2}{*}{$\begin{array}{l}\text { Viscos- } \\
\text { ity } \\
\text { Per cent }\end{array}$} & \multirow{2}{*}{$\begin{array}{l}\text { Vola- } \\
\text { tility } \\
\text { Sec. }\end{array}$} & \multirow{2}{*}{$\begin{array}{c}\text { Loss to } \\
\mathrm{H}_{2} \mathrm{SO}_{4} \\
\text { Per cent }\end{array}$} & \multicolumn{6}{|c|}{ Estimated per cent injury observed after } \\
\hline & & & & $20 \mathrm{hrs}$. & 25 hrs. & 2 da. & 4 da. & $6 \mathrm{da}$. & $10 \mathrm{da}$. \\
\hline 1 & 32 & $35.1 \%$ & 0.0 & 0 & 0 & 0 & 0 & 0 & 0 \\
\hline 2 & 83 & & 1.0 & 0 & 0 & 0 & 0 & 0 & $10 *$ \\
\hline 3 & 83 & $0.2 \%$ & 0.0 & 0 & 0 & 0 & 0 & 0 & $10^{*}$ \\
\hline 4 & 32 & $54.3 \%$ & 3.0 & 0 & 0 & 0 & 0 & 0 & 0 \\
\hline 5 & 83 & $1.0 \%$ & 9.0 & 0 & 40 & 80 & 90 & 100 & 100 \\
\hline 6 & 104 & $0.2 \%$ & 7.0 & 0 & 40 & 80 & 90 & 100 & 100 \\
\hline
\end{tabular}

* Finally, yeliowing and defoliation.

Tests of this kind illustrate strikingly the acute injury done by unsaturated oils. Twigs treated with unsaturated oils show almost complete blackening of the tissue within 48 hours, while it may be several days before the saturated oils cause injury, and even then the injury is not "burning" but "yellowing" and defoliation. The latter seems to be the result of suffocation of the cells in the tissue, while the action of the tunsaturated oils appears to be chemical for the most part. The very volatile oils leave the plant without causing injury. The important point in selecting an oil emulsion for spraying foliage is to use one that is as nearly inert chemically as possible. Such an emulsion is obtained with a saturated oil and an inert emulsifier. This conclusion is in harmony with deOng's. 


\section{Conclusions}

Emulsifying agents used in making oil enulsions for spray purposes vary in wetting ability, as measured by Stellwaag's angle-of-contact method, and consequently canse variations in the effectiveness of the emulsions. This is especially important in the control of aphids.

The stability of oil emulsions, which is indicated to some extent by the size of the globules, is one of the principal factors in insecticidal efficiency. The type of oil emulsified, the kind and amount of emulsifying agent, the quality of water used for dilution, and other factors commonly considered uniniportant, are capable of causing changes in stability and consequent fluctuations in efficiency.

Increased effectiveness may or may not be accompanied by an increase in the size of globules. Increased size of globules is the result of desirable qualities in an enulsion rather than the canse of effectiveness.

For use against aphids, the most effective emulsion is one that has high wetting ability coupled with instability. Either of these factors may vary so as to be dominant. A relatively "poor-wetting", unstable emulsion may be more effective on aphids than a "good-wetting". stable ennulsion. If the stability of two emulsions is about the same, then the one with the greater wetting ability is the more eftective on aphids.

In the control of scale insects, the instability of the emulsion is the printary consideration. The less stable the enulsion, the greater its efficiency. High wetting ability is not necessary for the control of San Jose scale and oyster-shell scale, becanse of the comparative ease with which their host plants are wetted. The emulsions used for the control of these insects should release quickly an oil of sufficiently high viscosity and low volatility to give a persistent residue.

I saturated oil, because of its influence in some cases on the stability of the enulsion, may be more effective than an unsaturated oil.

The amount of oil adhering and taking proper effect on the insect is dependent upon both the wetting ability and the instability of the emulsion. Inadequate wetting is a common cause of inefficiency, but excessive wetting. which results in some of the emulsion ruming off from objects that are easily wetted, is also a possible cause of inefficiency. These conditions are dependent on the kind of emtusion and the insect involved.

In order to be innocuous to plant foliage. an emulsion should be as inert chenically as possible. Soaps and unsaturated oils tend to injure foliage.

Each oil emulsion should he considered as a particular indiridual insecticide, having properties peculiar to itself and giving restilts that other emulsions may not. 


\section{ACKNOWLEDGMENTS}

The writer hereby expresses his gratitude to $\mathrm{Mr}$. IV. P. Flint, of the Illinois State Natural History Survey, for arranging many of the experiments and for suggestions and assistance from time to time: to Dr. B. A. Porter, of the U. S. Bureau of Entomology, for assistance, particularly with the San Jose scale experiments: and to Dr. W. A. Ruth, of the Horticultural Department of the University of Illinois, for the use of equipment and orchards, and for most friendly cooperation in every way.

For a careful criticism of the manuscript, the writer is grateful to Dr. F. W. Sullivan and Dr. E. W. Adams of the Standard Oil Company (Indiana). Thanks are due, also, to these chemists and other members of the Technical Department of the Standard Oil Company for assistance and cooperation at all times. Most of the emulsions used in the various experiments were prepared by the laboratories of the Standard Oil Company.

\section{Bibliography}

AnAi, Neil K., and Jessop, Gilbert

1925. Angles of contact and polarity of solid surfaces. Jour. Chem. Soc. 127: $1863-1868$.

Chander, S. C., Flixt, W. P., and Huber, L. L.

1926. Recent insecticide experiments in Illinois with lubricating oil emulsions. Ill. State Nat. Hist. Surv. Bull. 16: 103-126.

Cooper, W. F., and NetTall, W. H.

1915. The theory of wetting, and the determination of the wetting power of dipping and spraying fluids containing a soap basis. Jour. Agr. Sc. 7: 219-239.

DEONG, E. R.

1926. Tecbnical aspects of petroleum oils and oil sprays. Jour. Econ. Ent. 19: 733-745.

DeONg, E. R., Kxigit, H., and Chanberlin, J. C.

1927. A preliminary study of petroleum oil as an insecticide for citrus trees. Hilgardia. Calif. Agr. Exp. Sta. 2: 351-383.

Flixt, W. P., and Biggre, J. H.

1926. The fruit-tree leaf roller and its control under Illinois conditions. IIl. State Nat. Hist. Surv. Ent. Circ. 9.

Freundic'il, H.

1922. Colloid and capillary chemistry. Trauslation by Hatfield from the third German edition. Pub. by E. P. Dutton Co., New York.

Griffin, E. L., Richirisox, C. H., and Burdette, C.

1927. Relation of size of oil drops to toxicity of petroleum oil emulsions to aphids. Jour. Agr. Res. 34: 727-738.

H.rkins, W. D., Davies, E. C. H., and Clank, G. L.

1917. The orientation of molecules in the surface of liquids, etc. Jour. Amer. Chem. Soc. 39: 541-96. 
H.IWLY, I. M.

1926. The fruit-tree leaf roller and its control by oil sprays. Ctah $A g r$. Exp. sta. Bull. 196.

LIsT, G. MI.

1924. The oyster-shell scale. 11ith $4 \mathrm{~mm}$. Firpt. of the state Entomologist of Colo., 25-31.

MlFLAXIER, A. L., SPtLER, A.. and GReEx, E. L.

1924. Oil sprays-their preparation and use for insect control. Wash. Agr. Exp. sta. Bull. Ist.

Mooke, W., and Gruhu, S. A.

1918. Physical properties governing the efficacy of contact insecticides. Jowr. Agr. Res. 13: 523-537.

MOORE, W.

1921. The spreading and adherence of arsenical sprays. Cniv. Minn. Tceh. Bull. 2.

1923. The need of chemistry for the student of entomology. Jour. Econ. Ent. 16: 172-176.

Niтt.и.., W. H.

1920. Wetting power and its relation to industry. Jour. soe. Chem. Ind. 39: $67-77$.

Romisox, R. H.

1925. Spreaders for spray materials, and the relation of surface tension of solutions to their spreading qualities. Jour. Agr. Rrs. 31: $71-\$ 1$.

RíT11, W. A, and KÉl.Ley, Y. W.

1922. Recent advances in spraying. Trans. Ill. Hort. Soe. (n. s.) 56: 90-103.

S.IITII, LOREX B.

1916. Relationship between wetting power and efficiency of nicotinesulphate and fish-oil-soap sprays. Jour. Atr. Res. i: 3\$9-399.

STELLWAig, F.

1924. Die Benetzungsfäbigkeit flüssiger Pflanzenschutzmittel und ihre direckte Mlessbarkeit nach einem nenen Vertahren. Zeits. Anvex. Ent. 10: 163-176.

STLIAX, H. L

1920. A contribntion to the study of flotation. Trans. Inst. Min. Met. (London) 29: $44-208$.

Tr.ipplasi, T.

1926. Metloden zur Prïfung von Ptlanzenschutzmitteln. I. Benetzungsfähigkeit. Avb. Biol. Anst. 14: 259-266.

WaTiraso, Chatue.

1925. The fruit-tree leaf roller-its control in Sonthern Idaho by the use of oil emulsion sprays. Ilaho Agr. Erl). Sta. Bull. 137.

WogLtaI, R. S.

1925. The valne of sprays and fumigation for resistant black scale control. Bull. ('alif. Fruit Groucers Exch. (Los Angeles). 
WoOmax, R. Ml.

1924. The physics of spray liquids. I. The properties of wetting and spreading. Jour. Pom. Hort. Sci. 4: 38-58.

YoTHERS, W. W.

1924. Mixing emulsified mineral lubricating oils with deep-well waters and lime-sulphur solutions. U. S. Dept. Agr. Dept, Bull. 1217.

\section{Appondix $A$ \\ DEFINITIONS OF TERMS}

A saturated hydrocarbon is a compound of hydrogen and carhon in which the normal valence of carbon (four) is entirely satisfied.

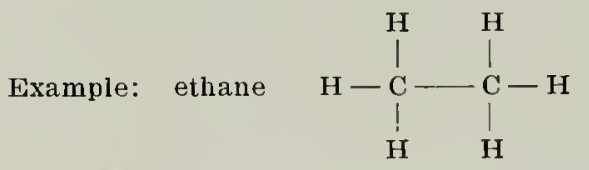

An unsaturated hydrocarbon is one in which the normal valence of carbon is not satisfied; hence, the compound is more active chemically than a saturated hydrocarbon.

Example: ethylene<smiles>C=C</smiles>

A saturated oil, or white oil, is one from which the unsaturated hydrocarbons have been removed by treatment with sulfuric acid. A saturated oil is practically inert chemically.

An unsaturated oil is not as highly refined as the white oils. While au oil of this kind may consist largely of saturated hydrocarbons, not all the unsaturated hydrocarbons have been removed in refining it.

Loss to Sulfuric Acid.* The loss in volume of an oil as a result of treatment with sulfuric acid is an index to the unsaturated hydrocarbon content. The greater the loss, the more unsaturated the oil. There is a standard method of procedure for this test.

Viscosity.* This is simply defined as resistance to flow, or negative fluidity. The standard of comparison used for oils is the Saybolt test. The units used are seconds, and they represent the time required for a given volume of oil to flow through a given orifice at a definite temperature.

Volatility $\cdot \dot{T}$ This is an arbitrary test which expresses as per cent by weight, the evaporation of a given quantity of oil at $212^{\circ} \mathrm{F}$ for 8 hours.

"Soluble Oil" and "Stock Emulsion". For purposes of discussion, a distinction is usually made between "soluble oil" and "stock emulsion", althongh there is no basic difference between them, both being oil emulsions. "Soluble oils," which are more or less transparent because of the extremely fine degree of dispersion of the oil phase, are compounded petroleum products which form milky-white emulsions when diluted with water. Dendrol and Sunoco are examples. The term "stock emulsion" is used with refereuce to a concentrated emulsion, such as Volck, Sherwin-Williams Free-mulsion, homemade lubricating oil emulsion, etc.

* The determinations of loss to sulfuric acid and of viscosity were made by the Standard Oil Company (Indiana) according to United States Government Specifications for Lubricants and Liquid Fuels and Methods of Testing, U. S. Bureau of Mines, Technical Paper 323 A., M1arch Is, 1924.

$\dagger$ Fefer to British Engineering Standards Association, Tentative British Standard specifications 148 (1923), pages $9-10$, Section 14 b. 


\section{Appendix $B$}

\section{EXPERINENTAL METHODS}

Tests on aphids. Aphis pomi De G. was obtained on the water sprouts of apple; Aphis spirafeoh Patch on Spiraea vunnuttei Zahel: Jesteroneura setariae Thos, on a grass (Echinichloa crusagalti I.); and Tritogenaphis ambrosiae Thos. on wild lettuce (Lactuca canadensis L.). The infested shoots were cut from the plants a short time before spraying. Nearly all the leaves were removed so that the aluhids would not be protected. The shoots were then placed vertically on a revolving stand and sprayed thoroughly witl a hand sprayer having bottom feed. An excessive amount of spray on the aphids was insured, i. e., as much as would adhere. After treatment, the shoots were inserted in holes in the tops of pill boxes filled with water and isolated on squares of paper bordered with tree tanglefoot. After approxinately 24 hours. the aphids were carefully removed with a camel's hair brush and counted.

Tests on oyster-shell scale. For the laboratory tests with oyster-shell scale. Lepidosaphes umi Linn., infested poplar (Populus deltoides Marsh) twigs were used. These were trimmed uniformly, and all scales were removed except 25 to 50 , the number varying with separate experiments, but never within one experiment. Five of these twigs were treated with each material, and several untreated checks of five twigs each were carried through each experiment. After treatment, the twigs were placed in a moist sand bench to grow. A ring of tanglefoot around each prevented the escape of "crawlers" at the time of hatching. Throughout the hatching period, the twigs were examined daily with a binocular microscope, and the crawlers were removed as counted. The checks usually hatched very uniformly, and the hatch on the treated blocks was calculated to "check basis". About 3,000 to 3,500 eggs hatched from each check block of five twigs.

Tests on San Jose scale. All of the tests of sprays on San Jose scale (Aspidiotus perniciosus Comstock) were conducted iu the field. In some cases, large infested branches were treated; in others, several entire trees were used in each block. The usual procedure of taking San Jose scale data was followed. A month or six weeks after treatment, twigs were collected from the various blocks, and a count of 1,000 scales was made to determine the percentage of survival. In making the counts, the scale was turned over in order that the insect itself might be seen. Robust, lenon-colored ones were recorded as "alive". Brown, black, shriveled, or "off color" ones were recorded as "dead."

\section{Appendix $C$}

\section{ANALYSIS OF TAP WATER LISED IN EXPERIMENTS}

Illinois State Water Survey, Sample No. 5172S, June 2S, 1924

Determinations

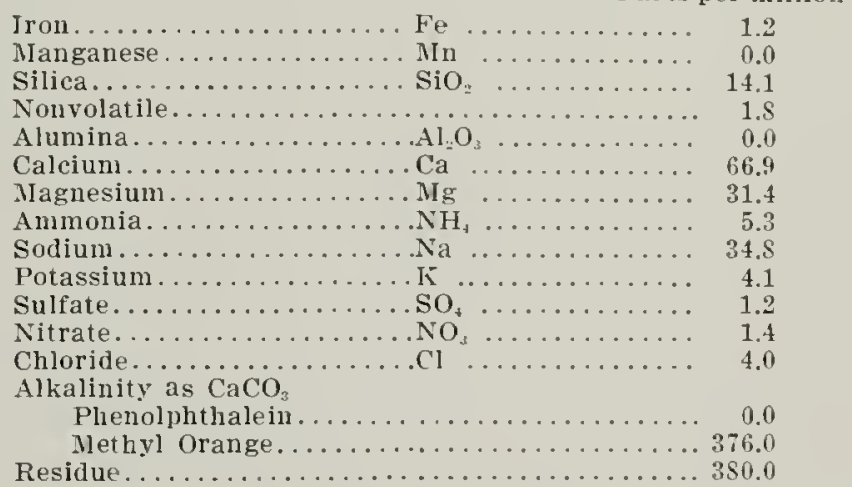

